\section{S.E. Olsen og medarbeidere svarer:}

Vi er glade for at vår artikkel om informasjon til pasienter i epidemiologiske studier har skapt engasjement. Vi ønsker velkommen en debatt om fordeler og ulemper ved forskningsinformasjon til pasienter og håper at den nasjonale forskningsetiske komite (NEM) og andre aktuelle aktører også tar opp ballen.

Kragerud Goplen og Roten mener at «det er viktig å gi god informasjon på riktig måte for å unngå misforståelser og engstelse» og påpeker at det er forskernes ansvar. Vi er enig med Retterstøl i at å avvise problemstillingen med at forskerne bare må gjøre en bedre jobb er altfor enkelt. Alle er selvsagt enige i at informasjon til pasienter bør skrives på en god måte. Men hva er en god måte? Når man ikke kjenner pasientenes bakgrunn er det vanskelig å ta hensyn til pasienters spesielle behov. Vårt overordnede poeng er imidlertid om pasientene i ikke-intervensjonsstudier trenger å vite om at de er med i forskning når det ikke har noen konsekvenser for dem eller andre. Dette krever en bred diskusjon slik at vi kan unngå at «det beste ikke blir det godes fiende», som Retterstøl skriver.

Kragerud Goplen er opptatt av Helsinki-deklarasjonen. Den inneholder overordnede etiske prinsipper som vi selvsagt er enig i. Det er de regionale etiske komiteer (REK) som har mandat til å bedømme etiske forhold i medisinsk og helsefaglig forskning. Hvis REK bedømmer at en studie er samfunnsnyttig, at den i liten grad innebærer ulemper for den enkelte, og at den enkeltes velferd eller integritet ikke krenkes, kan REK gi fritak fra taushetsplikten for innhenting av opplysninger, og fritak fra samtykkekravet. Det er altså REK som avgjør om pasienter skal informeres eller ikke.

Vi mener at REK kan gi fritak fra samtykkekravet for studier som ikke innebærer intervensjoner oftere enn hva som er praksis i dag.

\section{Sofia E. Olsen}

s.e.olsen@medisin.uio.no

Michael Bretthauer

Mette Kalager

Sofia E. Olsen (f. 1968) er rådgiver og prosjektkoordinator ved Universitetet i Oslo

Ingen oppgitte interessekonflikter.

Michael Bretthauer (f. 1969) er professor ved Universitetet i Oslo, overlege ved Gastromedisinsk seksjon, Avdeling for transplantasjonsmedisin, Oslo universitetssykehus og forsker ved forskningsgruppen Klinisk effektforskning ved Universitetet i Oslo/Oslo universitetssykehus. Ingen oppgitte interessekonflikter.

Mette Kalager (f. 1967) er lege, førsteamanuensis ved Universitetet i Oslo, forsker ved Avdeling for transplantasjonsmedisin, Oslo universitetssykehus og leder av forskningsgruppen Klinisk effektforskning ved Universitetet i Oslo/Oslo universitetssykehus.

Ingen oppgitte interessekonflikter.

Artikkelen Debatten rundt cannabis av Ø. Kristensen \& A. Mlodozeniec, som er publisert i Tidsskriftet nr. 5/2017, har utløst intens diskusjon på våre nettsider. Vi bringer her et utvalg.

\section{Re: Debatten rundt cannabis}

Øistein Kristensen \& Anita Mlodozeniec har skrevet et debattinnlegg om cannabis og rusdebatten (1). Her påstås det at man i NRKprogrammet Folkeopplysningen hevdet at cannabis er harmløst. Dette stemmer overhode ikke. Episoden problematiserte farene med cannabis ved å sette disse i sammenheng med velkjente rusmidler og andre farer. Denne rusformidlingen har godt empirisk belegg (2-4), og det kom godt frem i programmet at vi lever i en kultur med en utbredt feiloppfatning av bruksrisiko ved ulike rusmidler.
Det er typisk for rusdebatten at nyansert risikoformidling stemples som «ufarliggjøring», slik den gjøres av Kristensen \& Mlodozeniec. Men er det «ufarliggjøring» å formidle risiko med bruk av tallmessig sannsynlighet og i relasjon til kjente rusmidler som alkohol? Alternativet til slik formidling er å snakke høyt om hva som «kan skje». Dette er tvetydig, unyansert, og med dagens tilgang til internett, lett gjennomskuelig (5).

Det hevdes også av forfatterne at argumentene for å endre narkotikapolitikken ikke er forankret i forskning, men i «liberalistisk ideologi, brukeraktivisme og sterke kapitalkrefter». Mener forfatterne at dette også gjelder de seriøse aktørene som nå støtter en endring i dagens forbudspolitikk, slik som Verdens helseorganisasjon, UNAIDS, FNs utviklingsprogram, FNs menneskerettighetsråd og flere prestisjefylte medisinske tidsskrift (6-8)?

Det er med hensyn til folkehelsen at forfatterne ønsker å holde på forbudspolitikken. Dessverre vises det ikke til noe litteratur som skulle tilsi at denne løsningen er bra eller dårlig for folkehelsen. En slik referanse ville vært interessant, siden den hittil kanskje største og minst moraliserende litteraturgjennomgangen av ruspolitikk og folkehelse anbefaler avkriminalisering og en gradvis overgang til regulert omsetning (7). Som det fremkommer i litteraturgjennomgangen, og andre steder $(9,10)$, så er det usikkert om en liberalisering av ruspolitikken vil gi signifikante endringer i rusbruk, men det er særdeles godt dokumentert at det gir en rekke positive helsemessige og samfunnsøkonomiske virkninger.

\section{Andreas Wahl Blomkvist \\ andreas.wahl@gmail.com Fredrik Eika}

Andreas Wahl Blomkvist (f. 1989) er medisinstudent ved Aalborg Universitet, Danmark.

Ingen oppgitte interessekonflikter.

Fredrik Eika (f. 1989) er medisinstudent ved Aalborg Universitet, Danmark. Ingen oppgitte interessekonflikter.

\section{Litteratur}

1. Kristensen $\emptyset$. Mlodozeniec A. Debatten rundt cannabis. Tidsskr Nor Legeforen 2017; 137: 344

2. van Amsterdam J, Nutt D, Phillips L et al. European rating of drug harms. J Psychopharmacol 2015: 29: 655-60.

3. Nutt DJ, King LA, Phillips LD; Independent Scientific Committee on Drugs. Drug harms in the UK: a multicriteria decision analysis. Lancet 2010; 376: 1558-65.

4. van Amsterdam J, Opperhuizen A, Koeter M et al. Ranking the harm of alcohol, tobacco and illicit drugs for the individual and the population. Eur Addict Res 2010: 16: 202-7.

5. Blomkvist AW. Minas selvoppfyllende profeti. Ruspolitisk.no. https://ruspolitisk. no/minas-selvoppfyllende-profeti-e2f953915164 (7.3.2017).

6. Godlee F. Hurley R. The war on drugs has failed: doctors should lead calls for drug policy reform. BMJ 2016; 355: i6067

7. Csete J, Kamarulzaman A, Kazatchkine $\mathrm{M}$ et al. Public health and international drug policy. Lancet 2016; 387: 1427-80.

8. Blomkvist AW, Eika F, Eika S et al. Ny kurs for rusmidler. Tidsskr Nor Legeforen 2017: 137: $178-9$

9. Blomkvist AW. Krigen mot narkotika har feilet. Minerva 2016. https://www.minervanett.no/krigen-narkotika-feilet/ (7.3.2017)

10. Hari J. Chasing the Scream. New York: Bloomsbury, 2016.

\section{$\emptyset$. Kristensen \& A. Mlodozeniec svarer:}

Vi vil takke A.W. Blomkvist for hans kommentar hvor han gjentar de samme liberalistiske synspunkter som han har kommet med tidligere i Minerva og som ikke tilfører debatten noe nytt. Det som undrer oss er at han ikke tar opp problemene med den sterke cannabisen som var et hovedpunkt i vårt innlegg. Vi vil presisere at vi ikke har uttalt oss om avkriminalisering av besittelse og bruk av cannabis, men konsentrert oss om cannabis negative konsekvenser i tråd med WHO-rapporten (1).

Som klinikere er vi bekymret. Det er konsensus om at cannabisbruk fører til avhengighet hos 1 av 10, hos 1 av 6 dersom man starter som tenåring, og hos $25-50 \%$ hos dagligbrukere (1). Det er pasienter fra de to siste gruppene vi møter som behandlere. Antallet 